University of Wollongong

Research Online

Faculty of Engineering and Information

Faculty of Engineering and Information

Sciences - Papers: Part B

Sciences

2019

Transformation Behavior and Properties of Carbide-Free Bainite Steels with Different Si Contents

Junyu Tian

Wuhan University of Science and Technology

Guang Xu

Wuhan University of Science and Technology

Zhengyi Jiang

University of Wollongong, jiang@uow.edu.au

Xiangliang Wan

Wuhan University of Science and Technology

Haijiang Hu

Wuhan University of Science and Technology

See next page for additional authors

Follow this and additional works at: https://ro.uow.edu.au/eispapers1

Part of the Engineering Commons, and the Science and Technology Studies Commons

Research Online is the open access institutional repository for the University of Wollongong. For further information contact the UOW Library: research-pubs@uow.edu.au 


\title{
Transformation Behavior and Properties of Carbide-Free Bainite Steels with Different Si Contents
}

\author{
Abstract \\ The bainite transformation behavior and properties of low carbon carbide-free bainitic steels containing \\ different silicon $(\mathrm{Si})$ contents are investigated by two different types of heat treatment processes: \\ isothermal transformation process (ITP) and continuous cooling process (CCP). The results indicate that \\ for ITP and CCP, the transformation kinetics of bainite is retarded and the final bainite amount decreases \\ with increasing $\mathrm{Si}$ content. However, both the strength and total elongation improve with the increase of $\mathrm{Si}$ \\ content in the range of 1.0-2.0 wt\%, resulting in an apparent increment in comprehensive property of \\ bainitic steels due to the more film-like RA and less carbides. It can be attributed to the increase of shear \\ strength and stability of undercooled austenite and the formation of Cottrell atmosphere, as well as the \\ solid solution strengthening of Si because of higher Si content. In addition, for the same samples, better \\ mechanical properties can be achieved by a lower austempering temperature. Moreover, the increase of \\ Si content resulted in an increase in the temperatures of Ac1 and Ac3.

\section{Disciplines} \\ Engineering | Science and Technology Studies

\section{Publication Details} \\ Tian, J., Xu, G., Jiang, Z., Wan, X., Hu, H. \& Yuan, Q. (2019). Transformation Behavior and Properties of \\ Carbide-Free Bainite Steels with Different Si Contents. Steel Research International, 90 (3), \\ 1800474-1-1800474-11.
}

\section{Authors}

Junyu Tian, Guang Xu, Zhengyi Jiang, Xiangliang Wan, Haijiang Hu, and Qing Yuan 


\section{Contents} Junyu Tian ${ }^{1}$, Guang Xu ${ }^{1}$ *, Zhengyi Jiang ${ }^{2}$, Xiangliang Wan $^{1}$, Haijiang Hu ${ }^{1}$, Qing Yuan ${ }^{1}$

${ }^{1}$ The State Key Laboratory of Refractories and Metallurgy, Hubei Collaborative Innovation Center for Advanced Steels, Wuhan University of Science and Technology, 947 Heping Avenue, Qingshan District, Wuhan, 430081, China;

${ }^{2}$ School of Mechanical, Materials, Mechatronic and Biomedical Engineering, University of Wollongong, NSW, 2522, Australia;

*Corresponding author: Guang Xu;

Postal address: Mail Box 131, Wuhan University of Science and Technology, 947 Heping Avenue, Wuhan, Hubei, China;

Tel.: 86-027-68862813 ; Fax: 86-027-68862807

E-mail: xuguang@wust.edu.cn

Abstract: The bainite transformation behavior and properties of low carbon carbide-free bainitic steels containing different silicon ( $\mathrm{Si}$ ) contents were investigated by two different types of heat treatment processes: isothermal transformation process (ITP) and continuous cooling process (CCP). The results indicate that for ITP and CCP, the transformation kinetics of bainite was retarded and the final bainite amount decreased with increasing $\mathrm{Si}$ content. However, both the strength and total elongation improved with the increase of Si content in the range of $1.0 \mathrm{wt} \% \sim 2.0 \mathrm{wt} \%$, resulting in an apparent increment in comprehensive property of bainitic steels due to the more film-like RA and less carbides. It could be attributed to the increase of shear strength and stability of undercooled austenite and the formation of Cottrell atmosphere, as well as the solid solution strengthening of Si because of higher $\mathrm{Si}$ content. In addition, for the same samples, better mechanical properties can be achieved by a lower 
austempering temperature. Moreover, the increase of $\mathrm{Si}$ content resulted in an increase in the temperatures of $A c_{1}$ and $A c_{3}$.

Keywords: silicon; transformation; microstructure; properties; carbide-free bainite

\section{Introduction}

Advanced high strength steels (AHSS) have attracted more and more attention due to high strength and favorable ductility. The addition of nickel (Ni), molybdenum (Mo), chromium (Cr) and Silicon (Si) in $\mathrm{AHSS}^{[1-4]}$ are familiar to achieve superior performance. The choices of alloying elements not only affect the transformation behavior and microstructure, but further influences the mechanical properties of $\mathrm{AHSS}^{[5,6]}$. Therefore, in AHSS the optimization of the chemical composition is an important and attractive subject.

The alloying element, silicon ( $\mathrm{Si}$ ), is widely added in AHSS such as twining-induced plasticity (TWIP) steel, dual-phase (DP) steel, transformation-induced plasticity (TRIP) steel and carbide-free bainitic steels. The influences of Si on transformation behavior and mechanical properties of steels have been explored by many research groups. For example, Zhu et al. ${ }^{[7]}$ studied the influences of Si content on thermodynamic of austenite decomposition in C-Si-Mn TRIP steels and reported that Si accelerated the polygonal ferritic transformation and increased the volume fraction and stability of retained austenite (RA). Zhou et al. ${ }^{[8]}$ clarified the influences of $\mathrm{Si}$ on the transformation and mechanical properties in martensite-ferrite DP steels. They claimed that the finer ferrite grains and the higher carbon content in martensite were formed due to the addition of more amount of Si. Similarly, the effects of $\mathrm{Si}$ content on the evolution of microstructure and comprehensive properties were explored by Cai et al. ${ }^{[9]}$ in hot-rolled ferrite-bainite DP steels. The results revealed that the addition of Si promoted the formation of equiaxed and fine ferrite grains, and the mechanical properties were 
2 behavior and hot deformation behavior were examined by Li et al. ${ }^{[10]}$ in a Fe-Mn-Al TWIP steel. They propounded that in comparation to the Si-free steel, the addition of Si resulted in the higher strength and hardness due to the solution strengthening of Si atoms and higher work hardening ability.

In addition, regarding to the influences of Si content on bainite transformation and properties of low-carbon bainitic steels, some studies were also conducted. For example, Cai et al. ${ }^{[11]}$ explained the effects of $\mathrm{Si}$ on bainite microstructure and transformation in low-carbon bainitic steels during the continuous cooling process (CCP). They elucidated that the length of bainite ferrite laths obviously decreased in low Si bainitic steels, whereas the martensite/austenite (M/A) became more uniform in high Si bainitic steels after CCP treatment. Moreover, Zhang et al. ${ }^{[12]}$ also stated that the addition of $\mathrm{Si}$ led to the increase of the strength and toughness of low carbon bainitic steels through CCP treatment. However, these experiments were suffered from the decomposition of austenite into ferrite before bainite transformation so that the carbon content in undecomposed austenite must be changed due to the redundant carbon of ferrite partitioning, which will affect the real effect of Si addition on bainite transformation and properties. Furthermore, isothermal bainite transformation was a significant processing route to obtain the high strength bainitic steels, but the effects of Si content on isothermal bainite transformation are rarely investigated. Therefore, it is significant to explore the effect of $\mathrm{Si}$ content on bainite transformation, microstructure and mechanical properties of low-carbon carbidefree bainitic steels during isothermal transformation process.

Since Bhadeshia et al. ${ }^{[13}$ obtained the nanostructured bainite plates with ultrahigh strength and good toughness by austempering process, the research on bainite transformation during the isothermal transformation process has been an important topic. Si is a common element in bainite steels. But, as 

7 bainitic steels.

\section{8}

\subsection{Materials} embrittlement. ${ }^{[15]}$

Therefore, in this study, three low carbon bainitic steels containing different levels of Si were treated by two austempering processes and one continuous cooling process. The aim is to clarify the influences of Si content on bainite transformation, microstructure and mechanical properties of low carbon carbide-free bainitic steels during isothermal transformation process. The results provide references for the optimization of the chemical composition and processing technology of low carbon

\section{Materials and experimental procedures}

The experimental materials were refined in a $50 \mathrm{~kg}$ laboratory-scale vacuum furnace, then hot rolling to $12 \mathrm{~mm}$ thick plates in a four-high mill and finally air cooling to ambient temperature. Table 1 presented the chemical compositions of three tested bainitic steels. The addition of Mn was to improve the stability of metastable austenite and increase the hardenability of undercooled austenite. ${ }^{[14]}$ Molybdenum (Mo) was added to expedite the bainitic transformation and prevent temper

Table 1. Chemical compositions of three steels (wt\%).

\begin{tabular}{cccccccc}
\hline Steels & C & Si & Mn & Mo & N & P & S \\
\hline Si-1 & 0.221 & 1.002 & 2.189 & 0.219 & $<0.003$ & $<0.006$ & $<0.003$ \\
Si-2 & 0.219 & 1.503 & 2.201 & 0.221 & $<0.003$ & $<0.006$ & $<0.003$ \\
Si-3 & 0.220 & 2.012 & 2.197 & 0.218 & $<0.003$ & $<0.006$ & $<0.003$ \\
\hline
\end{tabular}

The bainite and martensite starting temperatures $\left(B_{S}\right.$ and $\left.M_{S}\right)$ for three tested steels were calculated by Equations (1) and (2), respectively. ${ }^{[16,17]}$ In addition, the $A c_{1}$ and $A c_{3}$ temperatures of three tested steels were determined using Andrews Equations (3) and (4). ${ }^{[18]}$ The corresponding calculated results are given in Table 2 .

$$
\text { Bs }\left({ }^{\circ} \mathrm{C}\right)=839-270\left[1-\exp \left(-1.33 x_{C}\right)\right]-86 x_{M n}-23 x_{S i}-67 x_{C r}-33 x_{N i}-75 x_{M o}
$$


Table 2. The corresponding critical temperatures for three tested steels.

\begin{tabular}{ccccc}
\hline Steels & $\mathbf{B}_{\mathbf{S}}\left({ }^{\circ} \mathrm{C}\right)$ & $\mathbf{M}_{\mathbf{s}}\left({ }^{\circ} \mathrm{C}\right)$ & $\mathbf{A c}_{\mathbf{1}}\left({ }^{\circ} \mathrm{C}\right)$ & $\mathbf{A c}_{\mathbf{3}}\left({ }^{\circ} \mathrm{C}\right)$ \\
\hline Si-1 & 541.8 & 333.6 & 728.6 & 865.7 \\
Si-2 & 530.3 & 328.0 & 743.1 & 888.1 \\
Si-3 & 518.8 & 322.5 & 757.7 & 910.4 \\
\hline
\end{tabular}

\subsection{Experimental procedures}

The thermal-mechanical simulation tests were performed on a Gleeble-3500 simulator. The cylindrical samples with $6 \mathrm{~mm}$ diameter and $100 \mathrm{~mm}$ height were prepared. The dilatations along the diameter direction were monitored during the whole experimental process. The sample with $6 \mathrm{~mm}$ diameter was used to minimize the temperature gradient along radial direction. The copper has an excellent thermal conductivity and copper clamps were used to minimize the temperature gradient in length direction.

Samples were treated by two different heat treatment procedures: isothermal transformation process (ITP) (containing two austempering temperatures) and continuous cooling process (CCP). For ITP, the samples were firstly austenitized at $1000{ }^{\circ} \mathrm{C}$ for $15 \mathrm{~min}$, then respectively cooled to $380{ }^{\circ} \mathrm{C}$ or $430{ }^{\circ} \mathrm{C}$ at $30{ }^{\circ} \mathrm{C} \mathrm{s}^{-1}$ and kept for $30 \mathrm{~min}$ for bainite precipitation, and finally, cooled to room temperature at $10^{\circ} \mathrm{C} \mathrm{s}^{-1}$ illustrated in Figure 1. For CCP, the same austenitizing process was designed and the heat treatment route for CCP is marked by dotted line in Figure 1. After austenization, the samples were fast cooled to $450{ }^{\circ} \mathrm{C}$ at $15^{\circ} \mathrm{C} \mathrm{s}^{-1}$, and then cooled to $350{ }^{\circ} \mathrm{C}$ at a slow cooling rate of $0.333{ }^{\circ} \mathrm{C} \mathrm{s}^{-1}$ for bainitic transformation and finally, cooled to room temperature at $10{ }^{\circ} \mathrm{C} \mathrm{s}^{-1}$. The 

rolling.

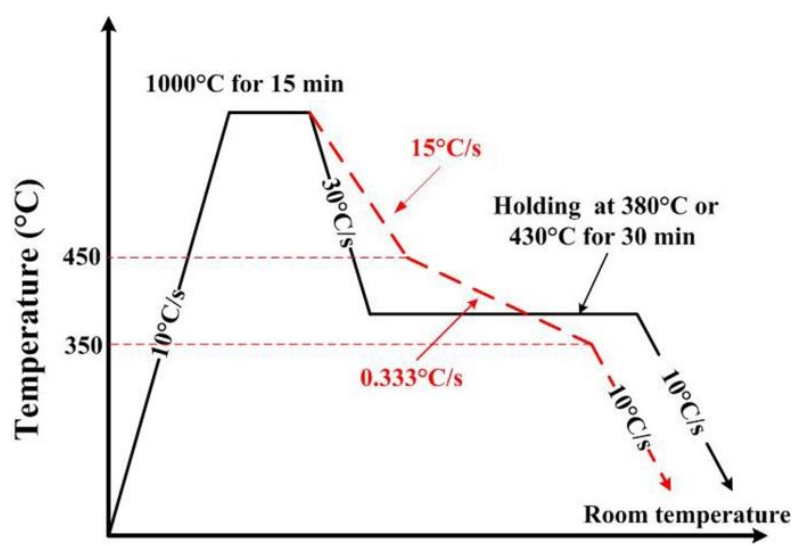

Time (s)

Figure 1. The experimental procedures.

\subsection{Examination}

After the corresponding heat treatments, a Nova 400 Nano field emission scanning electron microscope (FE-SEM) was used to determine the morphologies of microstructure and fracture. The Image-Pro Plus software (Media Cybernetics, Rockville, MD, USA) ${ }^{[19,20]}$ was utilized to count the volume fractions of bainite according to bainitic morphology and grayscale. To distinctly distinguish different transformation products, the micrographs with 5000× and $10000 \times$ magnifications were taken. Figure 2 shows the micrograph of $\mathrm{Si}-2$ steel isothermally transformed at $430{ }^{\circ} \mathrm{C}$ for $30 \mathrm{~min}$ and is used as an example to express the process of counting the volume fraction of bainite. The sample of Si-2 steel contains bainite, M/A island and RA marked in Figure 2a. The darker areas contain bainite and a portion of M/A shown in Figure 2a. Firstly, the darker areas were automatically colored to red and its area percentage (labeled as $B_{1}$ ) was counted by the Image-Pro Plus software (Figure $2 b$ ). Secondly, some blocky darker areas included in $\mathrm{B}_{1}$ were $\mathrm{M} / \mathrm{A}$ and should be subtracted. The blocky $\mathrm{M} / \mathrm{A}$ areas were manually and carefully marked by green (Figure 2c). The percentage of these areas was measured by the software and labeled as $B_{2}$. Finally, the area percentage of bainite (labeled as $B_{3}$ ) was attained by $\mathrm{B}_{3}=\mathrm{B}_{1}-\mathrm{B}_{2}$. In this example, $\mathrm{B}_{1}$ was $60.14 \%$ and $\mathrm{B}_{2}$ was $13.83 \%$, so that $\mathrm{B}_{3}$ was $46.31 \%$. Thus, the bainite volume fraction in Figure 2 a was $46.31 \%$. For the higher accuracy of statistical results, four 
typical SEM micrographs with various magnifications of every specimen were utilized and the average result was given in this study. Similarly, in other samples the volume fractions of bainite were

3 calculated in the same way.

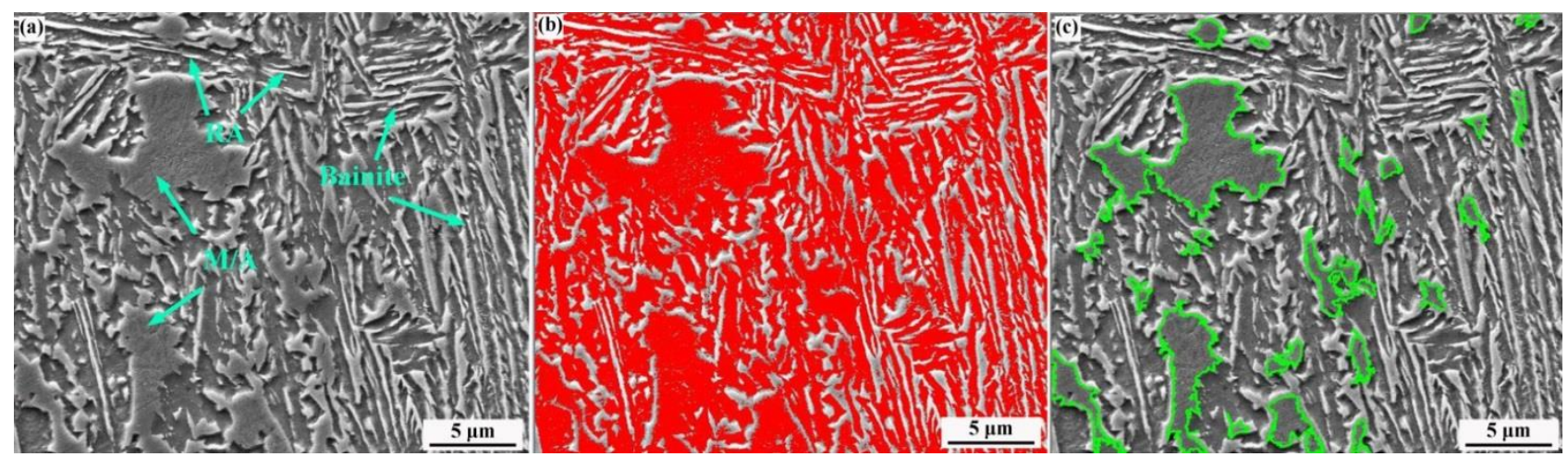

Figure 2. The example showing how to calculate the volume fraction of bainite: (a) the original

micrograph; (b) the darker areas in Figure 2a are colored red; and (c) the darker blocky areas are manually marked by green.

In addition, an UTM-4503 electronic universal tensile tester was utilized to conduct tensile tests with a $0.5 \mathrm{~mm} \mathrm{~min}{ }^{-1}$ cross-head speed at ambient temperature. Three repeated tensile tests were performed for each sample and the corresponding average results were given. It should be noted that the sub-size specimens were prepared in the tensile tests due to the dimension limits of thermal simulation specimens. It might cause possible deviation in tensile properties. However, the tensile properties of different specimens were comparable based on same tensile size. Moreover, X-ray diffraction (XRD) experiments were performed on an Empyrean diffractometer with filtered Co Ka radiation and $35 \mathrm{kV}$ and $50 \mathrm{~mA}$ operating parameters to determine the volume fractions of $\mathrm{RA}$. The step size and counting time were $0.0263^{\circ}$ and $77.265 \mathrm{~s}$, respectively.

\section{Results and discussion}

\subsection{Effect of Si content during ITP}

\subsubsection{Dilatation}

Figure 3 displays the curves of dilatation vs. temperature during the whole ITP process at $380{ }^{\circ} \mathrm{C}$ for three tested steels. The temperatures of $A c_{1}$ and $A c_{3}$ for $\mathrm{Si}-1, \mathrm{Si}-2$ and $\mathrm{Si}-3$ steels were measured to 
1 be $729^{\circ} \mathrm{C}$ and $861{ }^{\circ} \mathrm{C}, 749{ }^{\circ} \mathrm{C}$ and $872{ }^{\circ} \mathrm{C}$, and $765^{\circ} \mathrm{C}$ and $902{ }^{\circ} \mathrm{C}$, respectively. It is obvious that the

$2 A c_{1}$ and $A c_{3}$ temperatures increased with the increase of $\mathrm{Si}$ content. It was consistent with the

3 theoretical calculation values in Table 1. In addition, during cooling processes the dilatation curve of

4 Si-1 steel was a straight line from $1000{ }^{\circ} \mathrm{C}$ to point $\mathrm{A}\left(430{ }^{\circ} \mathrm{C}\right.$ in Figure $\left.3 \mathrm{a}\right)$ before austempering at

$5380{ }^{\circ} \mathrm{C}$, whereas those of $\mathrm{Si}-2$ and $\mathrm{Si}-3$ steels were straight lines from $1000{ }^{\circ} \mathrm{C}$ to isothermal

6 temperature of $380{ }^{\circ} \mathrm{C}$, indicating that there was no formation of high-temperature products because

7 of the high cooling rate of $30{ }^{\circ} \mathrm{C} \mathrm{s}^{-1}$ and only a small amount of bainitic transformation occurred in Si-

81 steel during the cooling process from $430^{\circ} \mathrm{C}$ to $380^{\circ} \mathrm{C}$. Besides, the obvious increase of the dilatation

9 during isothermal holding was caused by the bainitic transformation because the transformation 10 temperature was between $\mathrm{B}_{\mathrm{S}}$ and $\mathrm{M}_{\mathrm{S}}$.
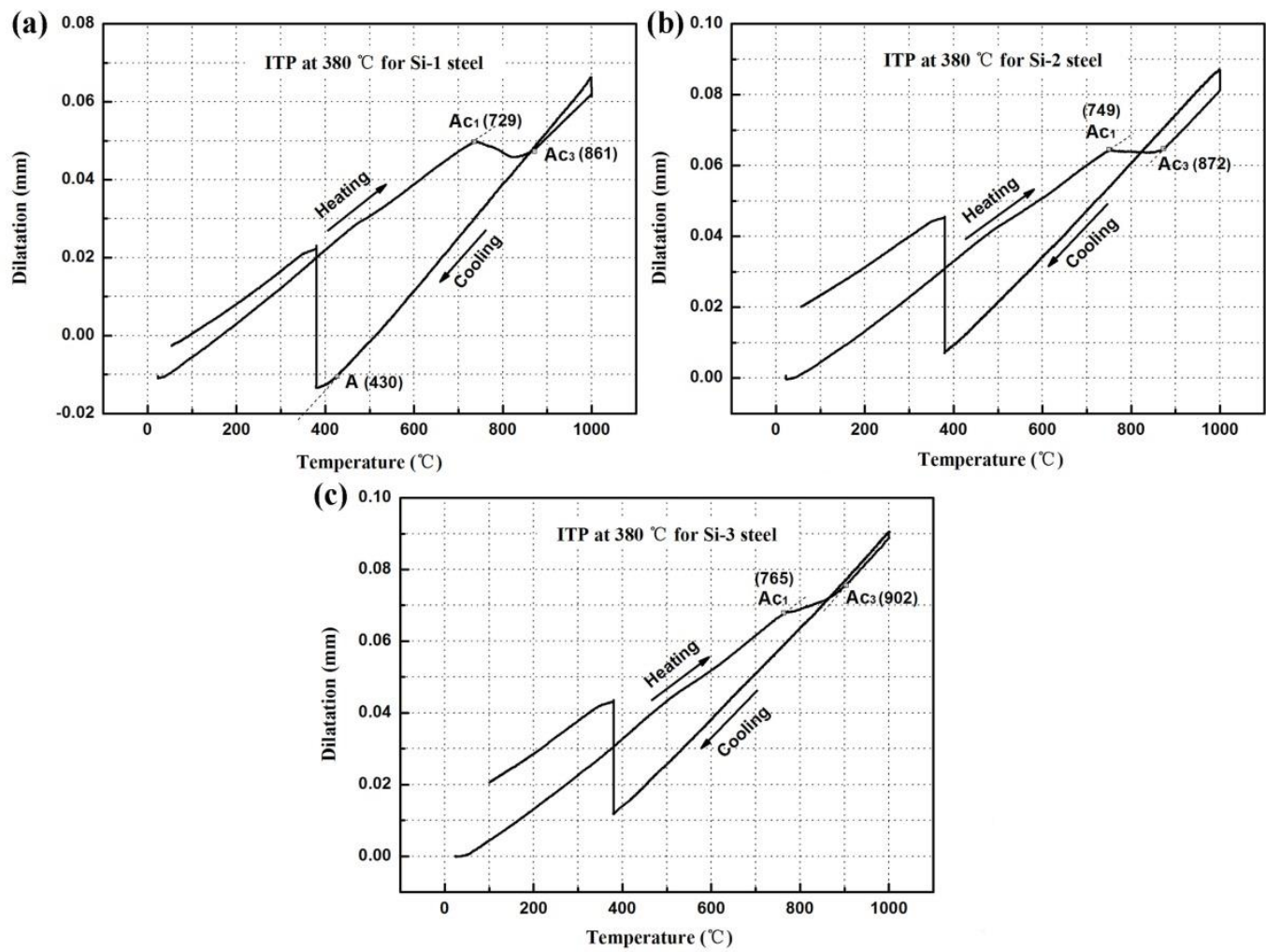

Figure 3. The dilatation versus temperature during the entire austempering treatments $\left(380{ }^{\circ} \mathrm{C}\right)$ for three steels: (a) $\mathrm{Si}-1$; (b) $\mathrm{Si}-2$ and (c) $\mathrm{Si}-3$.

Figures $4 \mathrm{a}$ and $4 \mathrm{~b}$ depict the dilatation (showing the transformation amount) vs. holding time curves during austempering at $380{ }^{\circ} \mathrm{C}$ and $430{ }^{\circ} \mathrm{C}$ for three steels, respectively. It can be observed that 
1 both the rate and the final bainite transformation amount decreased with increasing Si content when

2 the specimens were austempered at $380{ }^{\circ} \mathrm{C}$ and $430{ }^{\circ} \mathrm{C}$. Figure 5 represents the curves of time-

3 temperature-transformation (TTT) for three tested steels, which were calculated by the JMatPro7.0

4 software. ${ }^{[19]}$ The increase of Si content makes the ' $C$ ' curves of bainite starting transformation move

5 to right, indicating that increasing Si content prolongs the incubation period for bainitic transformation.

6 It demonstrates that the transformation kinetics of bainite is hindered with the increase of Si content.

7 It can be attributed to the following reasons. Firstly, Si addition strongly inhibits carbide precipitation

8 and thus enhances the chemical stability of undercooled austenite. ${ }^{[1]}$ The retardation of carbide

9 precipitation due to the increase of Si content results in the increase of carbon content in undercooled

10 austenite, which impedes the formation of carbon-depleted region for bainite nucleation and

11 growth, ${ }^{[9,11]}$ thus prolongs the incubation period of bainitic transformation. Secondly, carbon and Si atoms tend to aggregate in the dislocation area, which causes the Cottrell atmosphere to pin the dislocations, and thus increases the shear strength and stability of undercooled austenite. ${ }^{[21,22]}$ Therefore, the increase of Si content slows down the kinetics of transformation bainite and reduces the final bainite transformation amount.
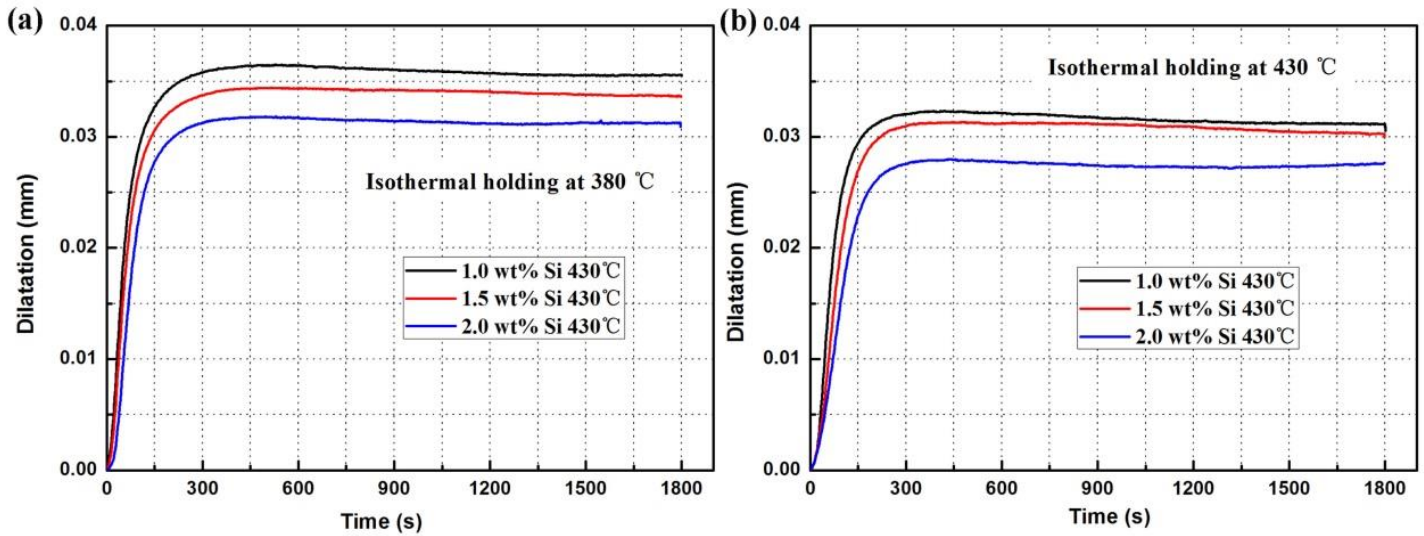

Figure 4. The dilatation versus time curves for three steels austempered at: (a) $380{ }^{\circ} \mathrm{C}$ and (b) $430{ }^{\circ} \mathrm{C}$. 


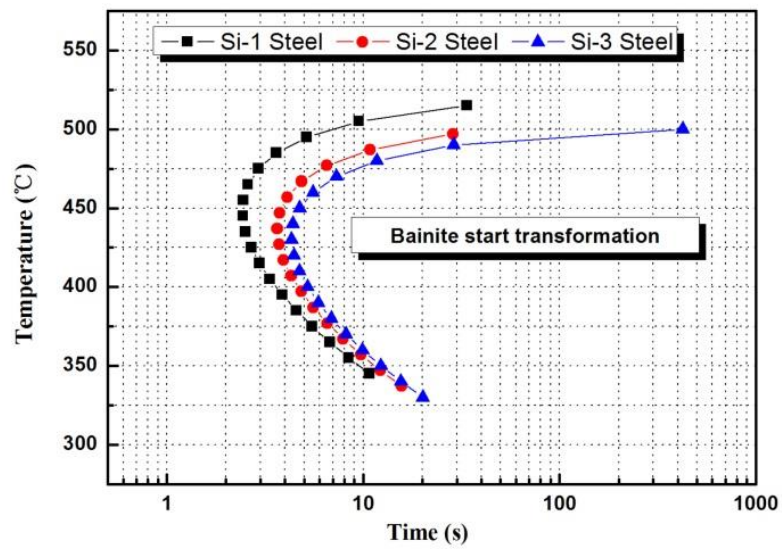

Figure 5. Calculated TTT curves of three steels showing the start of transformations from austenite to bainite.

\subsubsection{Microstructure}

The SEM microstructures of three tested steels austempered at different temperatures are shown in Figure 6. Figures 6a-c show the microstructure of samples austempered at $380{ }^{\circ} \mathrm{C}$ for $\mathrm{Si}-1, \mathrm{Si}-2$ and Si-3 steels, respectively, while Figures $6 \mathrm{~d}-\mathrm{f}$ are for three steels austempered at $430{ }^{\circ} \mathrm{C}$. The all microstructures mainly consisted of blocky M/A, bainite and film-like RA. The size of film-like RA changes from several nanometers to several hundred nanometers depends on compositions and treatment conditions. The film-like RA of several nanometers thick should be observed by transmission electron microscope (TEM). ${ }^{[23]}$ The bright films in Figure 6 are film-like RA of several hundred nanometers and these RAs can be clearly observed and confirmed by SEM. ${ }^{[24]}$ The film-like RAs are also confirmed by the magnified SEM microstructures (Figure 7). From the microstructure, it also can be observed that some carbide appeared in $\mathrm{Si}-1$ steel, but there was almost no carbide in $\mathrm{Si}-2$ and $\mathrm{Si}-3$ steels because the high content of $\mathrm{Si}$ in steels retarded the carbide precipitation. This kind of bainite in high-Si steels, which has little carbide between lath-like bainite (LB), is named by carbidefree bainite. ${ }^{[4-6]}$ Furthermore, for ITP at $380{ }^{\circ} \mathrm{C}$, there was a small part of granular bainite (GB) in the microstructure of Si-1 steel and it was very similar to the microstructure of the specimen austempered at $430{ }^{\circ} \mathrm{C}$. On the contrary, granular bainite was rarely observed in the specimens of steels $\mathrm{Si}-2$ and Si-3 austempered at $380{ }^{\circ} \mathrm{C}$. It indicates that some undercooled austenite of $\mathrm{Si}-1$ specimen was 
2 Figure $3 \mathrm{a}$.



Figure 6. The typical SEM microstructures of three tested steels treated by austempering at: (a)

In addition, based on the method described in Section 2.3, the volume factions of bainite in different specimens were calculated and presented in Table 3. It is observed that when three steels were austempered at same temperature $\left(380{ }^{\circ} \mathrm{C}\right.$ or $\left.430{ }^{\circ} \mathrm{C}\right)$, the amount of bainite transformation reduced with the increase of $\mathrm{Si}$ content. The statistic results were consistent with the dilatation values.

Besides, Figure 7 gives the magnified SEM microstructures of Si-1 and $\mathrm{Si}-3$ steels treated by isothermally transforming at $380^{\circ} \mathrm{C}$. It is observed that when the specimens were austempered at same temperature, the sizes of bainite and M/A islands decreased with the increase of Si content. It is attributed to the increase of shear strength and stability of undercooled austenite due to higher carbon content in metastable austenite and the formation of Cottrell atmosphere. Bhadeshia et al. ${ }^{[15,25]}$ reported that the microstructure of bainitic steels can be distinctly refined by enhancing the strength of austenite. 
1 Therefore, the sizes of bainite plates and blocky M/A gradually decreased with the increase of Si content.

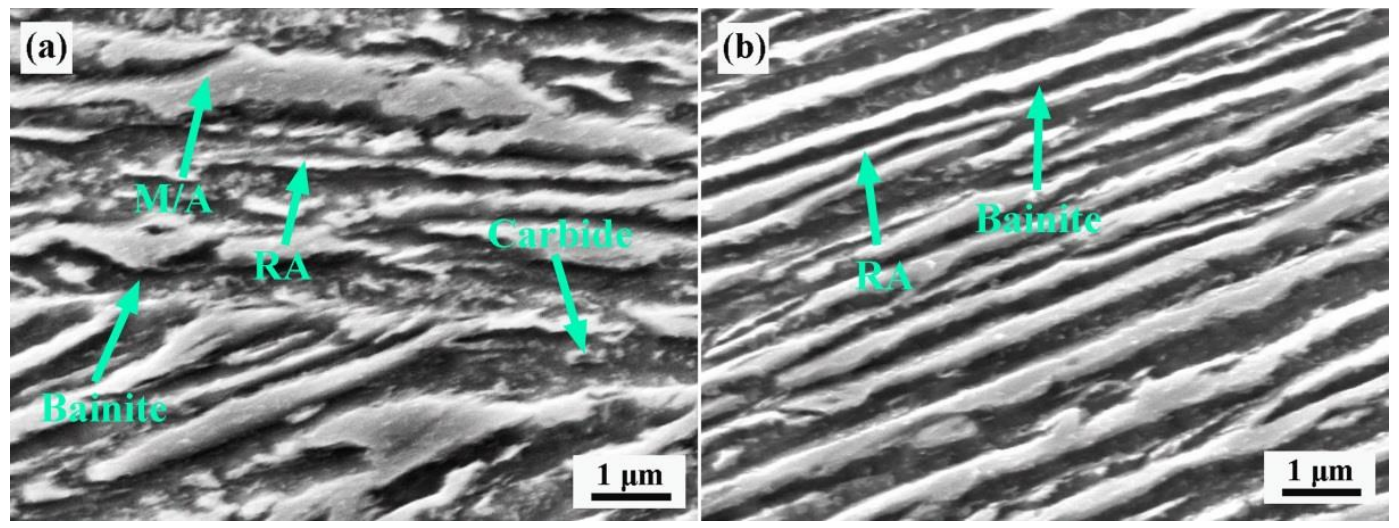

Figure 7. The magnified SEM microstructures: (a) Si-1 steel austempered at $380{ }^{\circ} \mathrm{C}$; (b) Si-3 steel austempered at $380{ }^{\circ} \mathrm{C}$.

For same steel, the lower transformation temperature resulted in more amount of bainite. It can be explained by $T_{0}$ theory. ${ }^{[26,27]}$ When the isothermal temperature decreases, the carbon storage capacity in undercooled austenite increases and thus more amount of bainite transformation can be obtained. Moreover, the decrease of isothermal temperature results in the increase of the undercooling for bainite transformation, which is conducive to the nucleation and growth of bainite. ${ }^{[28]}$ Thereby, lower austempering temperature resulted in more amount of bainite transformation.

Table 3. The volume fractions of bainite and RA.

\begin{tabular}{ccccc}
\hline Treatments & Steels & $\mathbf{V}_{(\mathbf{B})}(\mathbf{\%})$ & $\mathbf{V}_{(\mathbf{R A})}(\mathbf{\%})$ & $\mathbf{C}_{(\mathbf{R A})}(\mathbf{w t} \%)$ \\
\hline \multirow{2}{*}{ ITP at $380{ }^{\circ} \mathrm{C}$} & $\mathrm{Si}-1$ & $57.31 \pm 2.54$ & $3.38 \pm 0.76$ & $0.59 \pm 0.11$ \\
for $30 \mathrm{~min}$ & $\mathrm{Si}-2$ & $52.68 \pm 2.23$ & $6.59 \pm 1.46$ & $0.67 \pm 0.18$ \\
& $\mathrm{Si}-3$ & $49.22 \pm 1.95$ & $7.42 \pm 1.24$ & $0.95 \pm 0.04$ \\
\hline \multirow{2}{*}{ ITP at $430{ }^{\circ} \mathrm{C}$} & $\mathrm{Si}-1$ & $50.16 \pm 3.52$ & $8.12 \pm 2.16$ & $0.55 \pm 0.13$ \\
for $30 \mathrm{~min}$ & $\mathrm{Si}-2$ & $46.31 \pm 2.23$ & $11.45 \pm 0.83$ & $0.59 \pm 0.09$ \\
& $\mathrm{Si}-3$ & $43.84 \pm 2.56$ & $12.16 \pm 1.41$ & $0.77 \pm 0.05$
\end{tabular}

$\mathrm{V}_{(\mathrm{B})}, \mathrm{V}_{(\mathrm{RA})}$ and $\mathrm{C}_{(\mathrm{RA})}$ - the volume fractions of bainite and RA, and the carbon content in $\mathrm{RA}$

In addition, an example of the XRD diffraction pattern for $\mathrm{Si}-2$ steel isothermally transformed at $430{ }^{\circ} \mathrm{C}$ for $30 \mathrm{~min}$ is shown in Figure 8 . The volume fractions of RA in different specimens can be 
1 calculated according to the integrated intensities of $(200) \alpha,(211) \alpha,(200) \gamma,(220) \gamma$ and (311) $\gamma$

2 diffraction peaks by Equation (5). ${ }^{[29]}$

$$
V_{i}=\frac{1}{1+G\left(I_{\alpha} / I_{\gamma}\right)}
$$

4 where $V_{i}$ is the volume fraction of austenite for each peak, $I_{\alpha}$ and $I_{\gamma}$ are the corresponding integrated 5 intensities of martensite phase and austenite phase, $G$ is the ratio of the intensity factor corresponding 6 to the austenite crystal face $(h k l)_{j}$ and the martensite crystal face $(h k l)_{i}$. The value of $G$ is determined 7 as follows, 2.5 for $I_{\alpha}(200) / I_{\gamma}(200), 1.38$ for $I_{\alpha}(200) / I_{\gamma}(220), 1.78$ for $I_{\alpha}(200) / I_{\gamma}(311), 1.19$ for $8 I_{\alpha}(211) / I_{\gamma}(200), 0.06$ for $I_{\alpha}(211) / I_{\gamma}(220), 0.87$ for $I_{\alpha}(211) / I_{\gamma}(311)$, respectively. ${ }^{[29]}$ In addition, the 9 carbon content in RA $\left(\mathrm{C}_{\mathrm{RA}}\right)$ was determined based on the diffraction peaks position of $(200) \gamma,(220) \gamma$ 10 and (311) $\gamma$ by the method stated in reference. ${ }^{[30]}$ Table 3 gives the corresponding calculated results. 11 For the same austempering process, the carbon content in RA increased with increasing Si content. 12 Besides, the volume fraction of RA increased gradually from 3.38 vol. $\%$ to 7.42 vol. $\%$ at $380{ }^{\circ} \mathrm{C}$ and from 8.12 vol. $\%$ to 12.16 vol. $\%$ at $430{ }^{\circ} \mathrm{C}$ with increasing Si content from $1.0 \mathrm{wt} \%$ to $2.0 \mathrm{wt} \%$. This is because the amount of RA strongly depends on the amounts of bainite. It is known that bainite transformation is companied with the ejection of carbon atoms. ${ }^{[31]}$ The increase of $\mathrm{Si}$ content significantly hinders the formation of carbide, leading to the higher carbon content in undercooled austenite and the higher chemical stability. In the process of isothermal transformation and subsequent cooling, there was no carbide precipitation and less undercooled austenite was decomposed. Thus, more amount of RA with higher stability was retained in high-Si steel after ITP. 


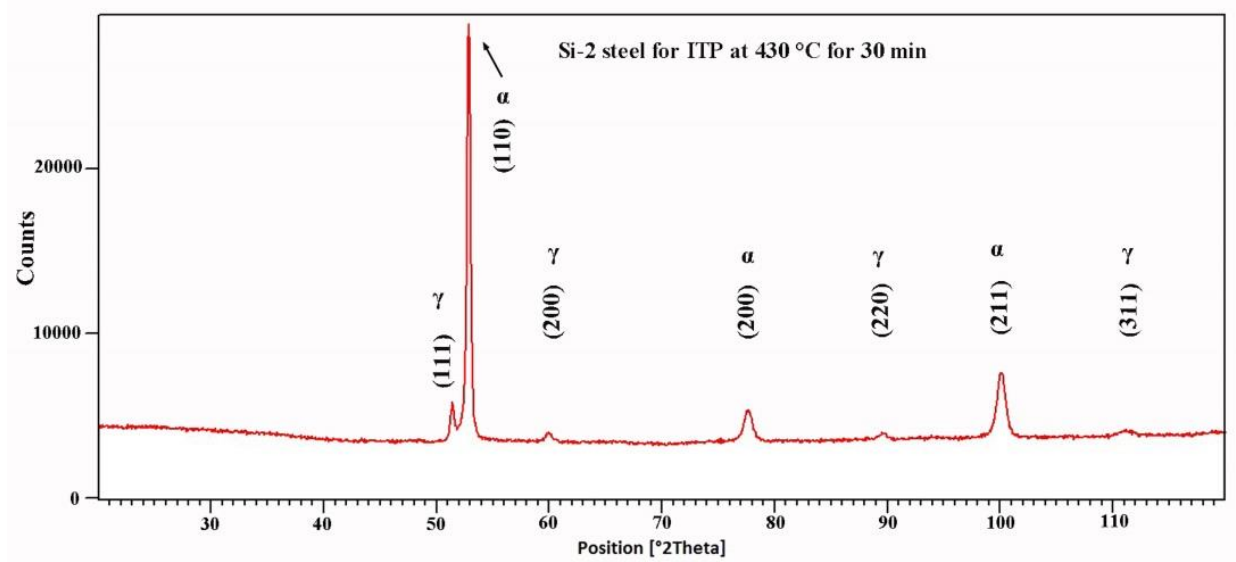

Figure 8. An example of XRD pattern for Si-2 steel austempered at $430{ }^{\circ} \mathrm{C}$ for $30 \mathrm{~min}$.

\section{$3 \quad 3.1 .3$. Tensile properties}

The tensile properties of different samples are shown in Table 4 and plotted in Figure 9. With the increase of Si content, both the total elongation (TE) and tensile strength (TS) increased slightly, resulting in an increment in the product of tensile strength and total elongation (PSE). It indicates that when the samples were treated by ITP, the tensile properties of steels could be improved by increasing $\mathrm{Si}$ content in the range of $1.0 \sim 2.0 \mathrm{wt} \%$. The tensile properties of steels are strongly related with microstructure. In high-Si steels, carbide precipitation is strongly inhibited, leading to the more RA with higher stability. The film-like RA with higher stability can significantly improve the mechanical properties through the TRIP effect. ${ }^{[20,32]}$ Apart from the TRIP effect, the finer microstructure in highSi samples also results in an improvement in mechanical properties. Moreover, Bhadeshia and Edmonds ${ }^{[33]}$ reported that carbides in martensite and bainite have great adverse effects on strength and toughness. The existence of carbides promotes the propagation and development of cracks and the nucleation of holes during the tensile process, significantly deteriorating the mechanical properties of low-Si steels. In high-Si steels, the carbon content in RA is enriched and the cementite between bainite plates is replaced by the film-like RA. The film-like RA with high stability has passivated effect on the development of the crack, which can increase the resistance of crack propagation and enhance the toughness and strength of the steel. 
Besides, the solid solution strengthening of $\mathrm{Si}$ also contributes to the improvement of strength.

The relationship between Si content and tensile strength can be expressed by the Equation (6). ${ }^{[34]}$

$$
\Delta \sigma_{s}(\mathrm{MPa})=4750 x_{C}+3750 x_{N}+37 x_{M n}+84 x_{S i}
$$

where $\Delta \sigma_{s}$ is the value of solid solution strengthening and $x_{i}$ is the mass percent of element " $i$ ". It is

known that the effect of solid solution strengthening increases with the increase of Si content.


Figure 9. The comprehensive properties of different specimens.

Table 4. The tensile results of different specimens treated by ITP.

\begin{tabular}{cccccr}
\hline Treatments & Steels & TS (MPa) & YS (MPa) & TE(\%) & \multicolumn{1}{c}{ PSE(GPa\%) } \\
\hline \multirow{2}{*}{ ITP at $380{ }^{\circ} \mathrm{C}$} & $\mathrm{Si}-1$ & $1011 \pm 12$ & $719 \pm 22$ & $11.74 \pm 0.21$ & $11.869 \pm 0.397$ \\
for $30 \mathrm{~min}$ & $\mathrm{Si}-2$ & $1027 \pm 19$ & $738 \pm 16$ & $13.45 \pm 0.32$ & $13.813 \pm 0.258$ \\
& $\mathrm{Si}-3$ & $1059 \pm 23$ & $791 \pm 21$ & $14.78 \pm 0.44$ & $15.652 \pm 0.623$ \\
\hline \multirow{2}{*}{$\mathrm{SP}$ at $430{ }^{\circ} \mathrm{C}$} & $\mathrm{Si}-1$ & $892 \pm 16$ & $619 \pm 26$ & $10.45 \pm 0.18$ & $9.325 \pm 1.087$ \\
for $30 \mathrm{~min}$ & $\mathrm{Si}-2$ & $941 \pm 18$ & $685 \pm 17$ & $13.83 \pm 0.21$ & $13.014 \pm 0.365$ \\
& $\mathrm{Si}-3$ & $1026 \pm 26$ & $712 \pm 29$ & $13.89 \pm 0.42$ & $14.251 \pm 0.472$ \\
\hline
\end{tabular}

YS - the yield strength, TS - the tensile strength, TE-the total elongation

In addition, it is known from the tensile results that for same steel, when the samples are austempered at lower temperature of $380{ }^{\circ} \mathrm{C}$, the higher PSE can be obtained. According to the SEM microstructure (Fig. 6), the amounts of lath-like bainite and film-like RA increase with the decrease of 
austempering temperature, which improves the mechanical properties of tested steel. It should be pointed out that the sample transformed at higher austempering temperature contains more amount of RA than the sample treated at lower austempering temperature. But most of RA in the former presents blocky morphology. The blocky RA is not stable and easily decomposes at the beginning of tensile test, resulting in smaller contribution to PSE.

\section{3.2. Effect of Si content during CCP}

\subsubsection{Dilatation}

Figure 10a illustrates dilatation as a function of temperature for $\mathrm{Si}-1$ steel during the whole CCP. It was a straight line from austenization temperature of $1000{ }^{\circ} \mathrm{C}$ to point $\mathrm{n}\left(507{ }^{\circ} \mathrm{C}\right.$ below $\left.\mathrm{B}_{\mathrm{S}}\right)$, indicating that the high-temperature products were avoided due to the cooling rate of $15^{\circ} \mathrm{C} \mathrm{s}^{-1}$ and the deviation of dilatation curves at point $\mathrm{n}$ was caused by bainite transformation. Moreover, the turning point $(\mathrm{m})$ in the dilatation curve represents the starting point of martensite transformation. Figure $10 \mathrm{~b}$ shows dilatation as a function of time during $\mathrm{CCP}$ from $450{ }^{\circ} \mathrm{C}$ to $350{ }^{\circ} \mathrm{C}$. It can be observed that the kinetics of baintic transformation was hindered with the increase of Si content. It was consistent with the result in ITP. Moreover, there was an obvious decline in dilatation curve of Si-1 steel from $175 \mathrm{~s}$ to $300 \mathrm{~s}$, whereas it seems to be a horizontal line in $\mathrm{Si}-2$ and $\mathrm{Si}-3$ steels. It indicates that the bainite transformation of Si-1 samples basically stopped after $175 \mathrm{~s}$, but the bainite transformation of Si-2 and was basically equal to the decrease in dilatation due to the drop of temperature.

Figure 10. For CCP: (a) dilatation curves versus temperature of Si-1 steel and (b) dilatation versus time of three steels from $450{ }^{\circ} \mathrm{C}$ and $350{ }^{\circ} \mathrm{C}$.

\subsubsection{Microstructure}

Figure 11 gives the microstructures of different steels treated by CCP. It can be observed that the amount of granular bainite gradually decreased and the lath-like bainite amount gradually increased with increasing Si content. In comparison to low-Si steel, higher Si content in high-Si steel led to less amount of carbides, resulting in higher chemical stability of undercooled austenite, and thus prolonged the incubation period and brought the formation of lower temperature bainite. Therefore, with the increase of Si content, more undercooled austenite was transformed into lath-like bainite instead of granular bainite. Moreover, the size of baintie plates decreased with increasing Si content due to the higher shear strength and stability of austenite. ${ }^{[14,22]}$ Meanwhile, the RA volume fractions in different samples were determined by XRD experiments using the method described in Section 3.1.2. They were $5.37 \%, 7.03 \%$ and $9.27 \%$ for $\mathrm{Si}-1, \mathrm{Si}-2$ and $\mathrm{Si}-3$ steels, respectively, indicating that the volume fraction of RA gradually increased as Si content increased.
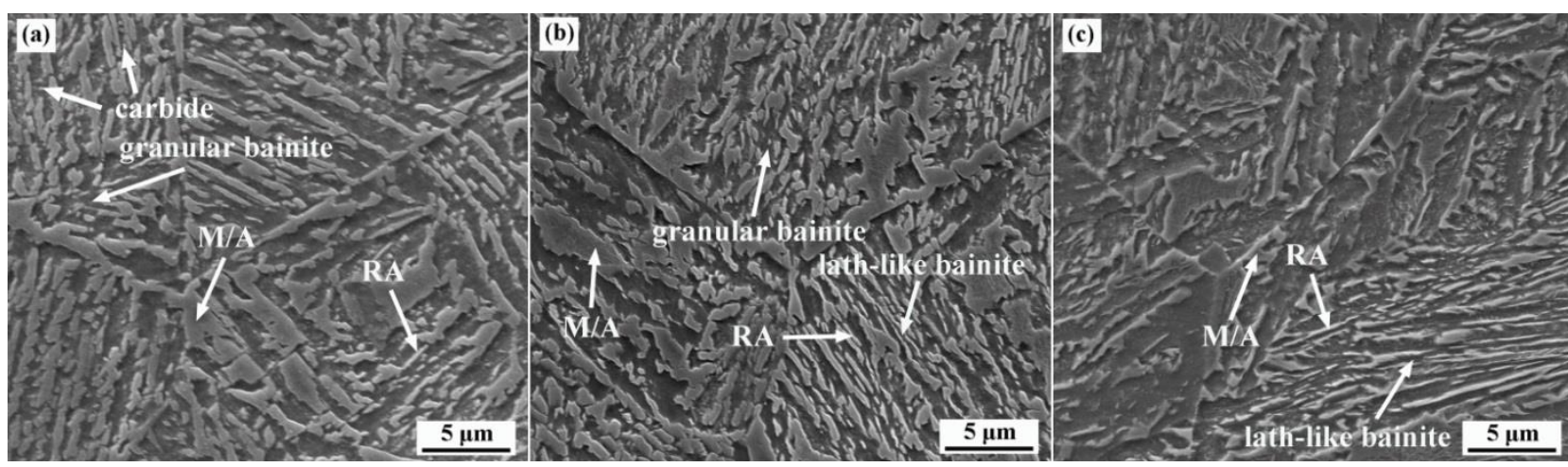

Figure 11. The microstructures of different steels treated by CCP: (a) Si-1; (b) Si-2; and (c) Si-3.

\subsubsection{Tensile properties}

Figure 12 gives the typical engineering stress-strain curves and Table 5 lists the tensile results of different samples treated by CCP. The sample of Si-3 steel achieved the highest TS of $991 \mathrm{MPa}$ and the best TE of $14.25 \%$, resulting in the largest PSE of $14.12 \mathrm{GPa} \%$ with increasing Si content from 1.0 $\mathrm{wt} \%$ to $2.0 \mathrm{wt} \%$. It means that when the samples were treated by CCP, an increase of Si content brought 
better mechanical properties in Si content of $1.0 \mathrm{wt} \%$ 2.0 wt $\%$. It is shown in Figure 11 that increasing

2 Si content resulted in more amounts of lath-like bainite and film-like RA. The film-like RA is favorable

3 for the improvement of the comprehensive properties of bainitic steels by the TRIP effect. Moreover,

4 the appearance of carbides in low-Si steel also deteriorated the mechanical properties of bainitic steels.

5 Thus, when the steels were treated by CCP, increasing Si content improved the mechanical properties

6 of low carbon bainitic steels. In addition, it is observed from tensile results (Tables 4 and 5) that for

7 same steel, the mechanical properties of samples treated by ITP are slightly better than the sample

8 treated by CCP. It can be attributed to the existence of more granular bainite and coarser bainite plate

9 in the samples treated by CCP.

Table 5. The tensile results of different samples treated by CCP.

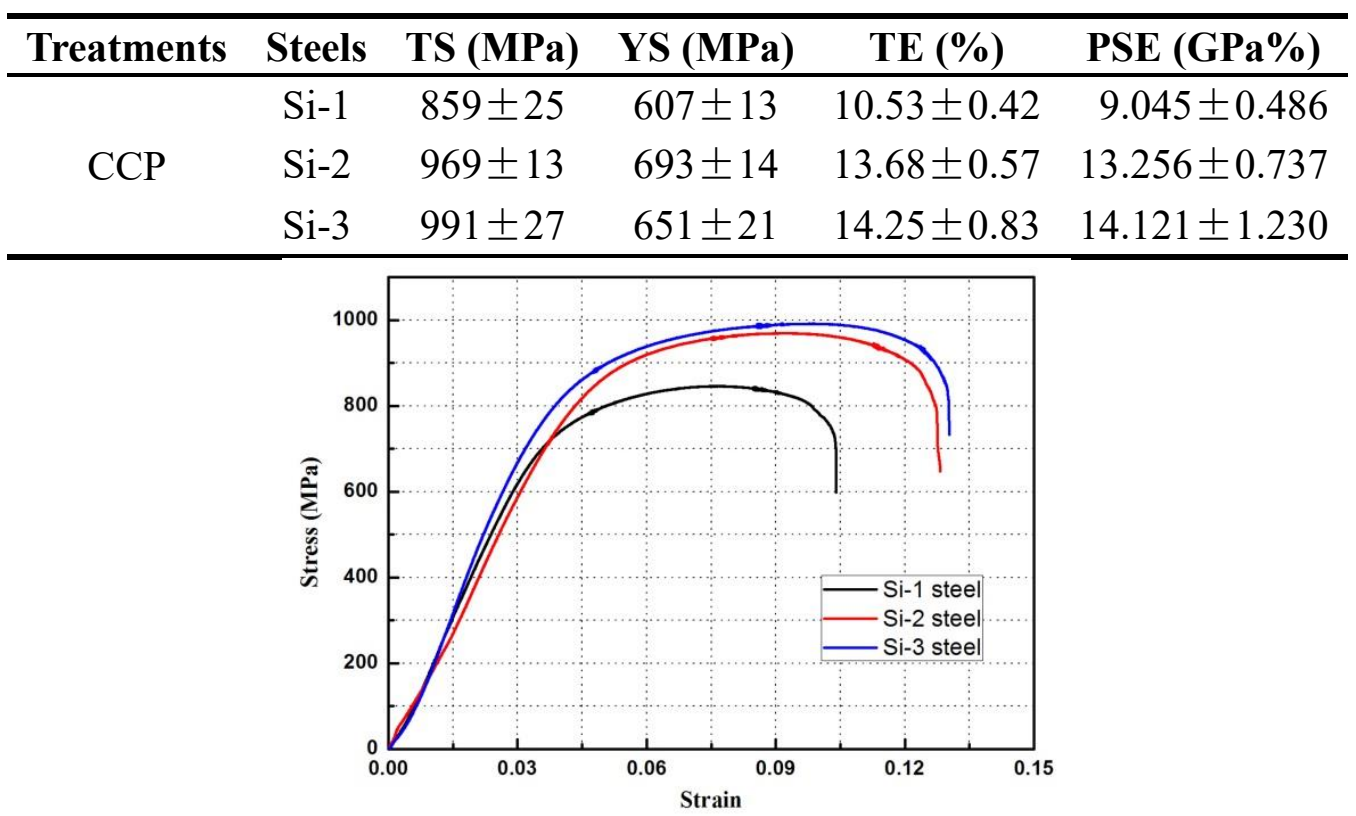

Figure 12. Typical tensile curves of different samples treated by CCP.

The fracture morphologies of different tensile samples are presented in Figure 13. Both cleavage facet and ductile tearing were observed in all specimens. It is known that brittle fracture mode leads to cleavage facet, meaning the inferior tensile toughness. Oppositely, ductile fracture results in ductile tearing, implying the high tensile toughness. ${ }^{[19,35]}$ The fracture surface of Si-1 steel consisted of more amount of cleavage facets, while more amount of ductile tearing morphology appeared in the specimens of $\mathrm{Si}-2$ and $\mathrm{Si}-3$ steels. Moreover, the voids were clearly observed in fracture microstructure 
of $\mathrm{Si}-1$ steel, but no voids were found in $\mathrm{Si}-2$ and $\mathrm{Si}-3$ steels. The formation of voids in low-Si steel,

2 significantly deteriorating the toughness of steel, may be due to the carbide. Therefore, the tensile

3 toughness increased with increasing Si content, which was consistent with the results in Table 5.

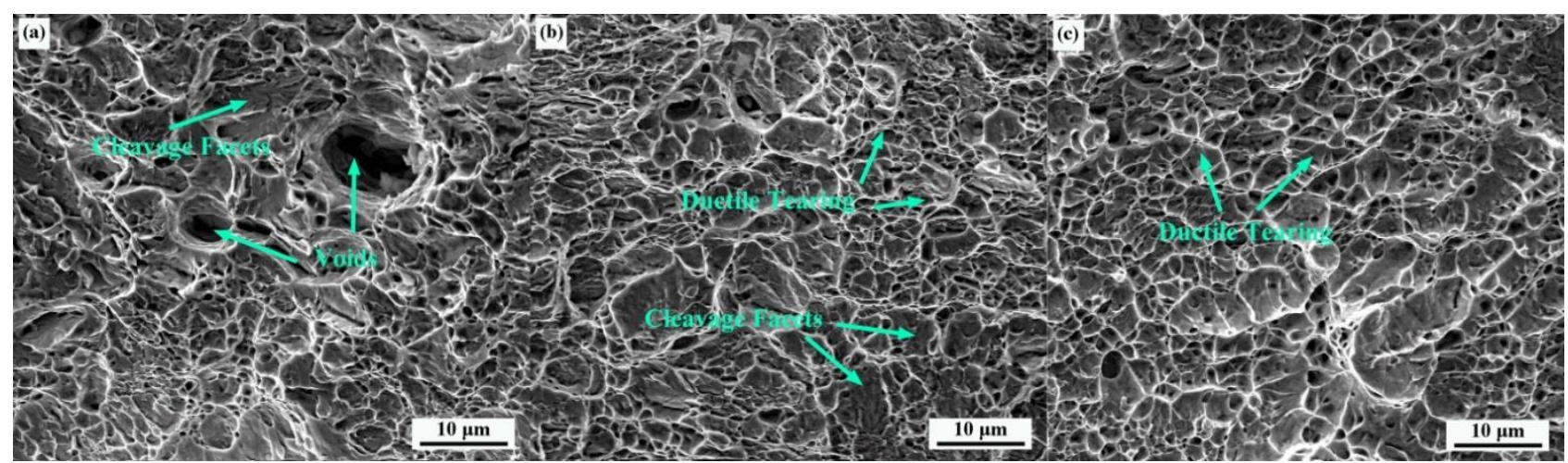

Figure 13. SEM micrographs of the fracture surface of the tensile specimens at room temperature:

(a) Si-1 steel; (b) Si-2 steel and (c) Si-3 steel.

\section{Conclusions}

The effects of Si content on bainite transformation, microstructure and properties in $0.22 \mathrm{wt} \%$ carbon carbide-free bainite steels were investigated by ITP and CCP processes. The following conclusions can be drawn:

(1) For both ITP and CCP processes, with the increase of Si content, the kinetics of bainite transformation was hindered and the final amount of bainite transformation decreased because higher Si content inhibits the formation of carbide and brings the increase of shear strength and stability of undercooled austenite, as well as the formation of Cottrell atmosphere.

(2) The comprehensive properties of bainitic steels could be improved by increasing the Si content for both ITP and CCP processes in the range of $1.0 \mathrm{wt} . \%$ 2.0 wt.\%. It is mainly because the increase of Si content results in more amount of film-like RA and less amount of carbides. Besides, the solid solution strengthening of $\mathrm{Si}$ also results in the increment of strength. 
(3) For ITP, the higher PSE can be obtained in samples austempered at a lower temperature.

2 Moreover, the mechanical properties of samples treated by ITP are slightly better than the sample 3 treated by CCP.

$4 \quad$ (4) The temperatures of $A c_{1}$ and $A c_{3}$ increased with the addition of Si.

\section{Acknowledgements}

6 The authors gratefully acknowledge the financial supports from the Major Projects of Technological

7 Innovation in Hubei (No.2017AAA116), the National Natural Science Foundation of China (No.

8 51874216), the National Nature Science Foundation of China (No.51704217), and the State

$9 \quad$ Scholarship Fund of China Scholarship Council.

10 Abbreviations

11 The following abbreviations are used in this manuscript:

12 AHSS Advanced high strength steel

13 DP dual-phase

14 TWIP twining-induced plasticity

15 TRIP transformation induced plasticity

16 CCP continuous cooling process

17 ITP isothermal transformation process

18 RA retained austenite

$19 \mathrm{~B}_{\mathrm{S}} \quad$ bainite starting temperature

$20 \mathrm{Ms}_{\mathrm{S}}$ martensite starting temperature

$21 \mathrm{Ac}_{1} \quad$ austenitization starting temperature during heating

$22 \mathrm{Ac}_{3}$ austenitization finishing temperature during heating

23 SEM scanning electron microscope

24 XRD X-ray diffraction

$25 \mathrm{M} / \mathrm{A}$ martensite/austenite island

26 YS yield strength

27 TS tensile strength 
1 TE total elongation

2 PSE product of the tensile strength and total elongation

3 TTT time-temperature-transformation

\section{$4 \quad$ References}

$5 \quad$ 1. L. C. Chang, Metall. Mater. Trans. A 1999, 30, 909.

6 2. I. Tsukatani, S. Hashimoto, T. Inoue, ISIJ Int. 2007, 31, 992.

7 3. S. H. Bae, H. W. Lee, Met. Mater. Int. 2013, 3, 563. A. Jahn, A. Kovalev, A. Weiß, P. R. Scheller, $8 \quad$ Steel Res. Int. 2011, 82, 1108.

9 4. M. X. Zhou, G. Xu, J. Y. Tian, H. J. Hu, Q. Yuan, Metals, 2017, 7, 263.

10 5. H. J. Hu, G. Xu, L. Wang, Z. L. Xue, Y. L. Zhang, G. H. Liu, Mater. Des. 2015, 84, 95.

11 6. J. Y. Tian, G. Xu, M. X. Zhou, H. J. Hu, X. L. Wan, Metals, 2017, 7, 40.

12 7. L. J. Zhu, D. Wu, X. M. Zhao, J. Iron and Steel Res. Int. 2006, 13, 57.

8. L. Y. Zhou, D. Zhang, Y. Z Liu, Int. J. Min. Metall. Mater. 2014, 21, 755.

9. M. H. Cai, H. Ding, Y. L. Lee, Z. Y. Tang, J. S Zhang, ISIJ Int. 2011, 51, 476.

10. D. J. Li, Y. R. Feng, S. Y. Song, Q. Liu, Q. Bai, F. Z. Ren, F. S. Shangguan, J. Alloys Compd. 2015,

11. M. H. Cai, H. Ding, J. S. Zhang, L. Li, X. B. Li, L. X. Du, J. Iron and Steel Res. Int. 2009, 16, 55.

12. M. X. Zhang, M. K. Kang, Acta Metall. Sinica, 1993, 29, 6.

13. F. G. Caballero, H. K. D. H. Bhadeshia, K. J. A. Mawella, D. G. Jones, P. Brown, Mater. Sci. Technol. 2002, 18, 279.

14. X. Y. Long, F. C. Zhang, J. Kang, B. Lv, X. B. Shi, Mater. Sci. Eng. A 2014, 594, 344. 
17. P. Payson, C. H. Savage, ASM-Trans, 1944, 33, 261.

18. K. W. Andrews, ISIJ Int. 1965, 203, 721.

19. J. Y. Tian, G. Xu, Z. Y. Jiang, H. J. Hu, M. X. Zhou, Met. Mater. Int. 2018, doi: 10.1007/s12540018-0139-y.

20. J. Y. Tian, G. Xu, M. X. Zhou, H. J. Hu, Steel Res. Int. 2018, doi: 10.1002/srin.201700469.

21. J. Z. Zhao, A. K. De, B. C. D. Cooman, Mater. Lett. 2000, 44, 374.

22. A. Portavoce, G. Tréglia, Acta Mater. 2014, 65, 1.

23. L. C. Chang, H. K. D. H. Bhadeshia, Mater. Sci. Technol. 1995, 11, 874.

24. M. X. Zhou, G. Xu, H. J. Hu, Q. Yuan, J. Y. Tian, Steel Res. Int. 2017, 88, 1.

25. S. B. Singh, H. K. D. H. Bhadeshia, Mater. Sci. Eng. A 1998, 245, 72.

26. J. Y. Tian, G. Xu, L. Wang, M. X. Zhou, H. J. Hu, Trans. Indian Inst. Met. 2018, 71, 185.

27. H. K. D. H. Bhadeshia, S. A. David, J. M. Vitek, R.W, Mater. Sci. Technol. 1991, 7, 686.

28. M. X. Zhou, G. Xu, L. Wang, H. J. Hu, Trans. Indian Inst. Met. 2016, 69, 693.

29. C. Y. Wang, J. Shi, W. Q. Cao, H. Dong, Mater. Sci. Eng. A 2010, 527, 3442.

30. M. X. Zhou, G. Xu, L. Wang, B. He, Trans. Indian Inst. Met. 2017, 70, 1447.

31. C. F. Garcia, S. M. Jesus, C. Capdevila, G. M. Carlos, G. D. A. Carlos, ISIJ Int. 2006, 46, 1479.

32. N. Lim, H. Park, S. Kim, C. Park, Met. Mater. Int. 2012, 18, 647.

33. H. K. D. H. Bhadeshia, D. V. Edmonds, Metall. Trans. A, 1979, 10, 895.

34. Q. Yuan, G. Xu, B. He, M.X. Zhou, Hot Working Technol. 2016, 45, 85.

35. G. Mandal, C. Roy, S. K. Ghosh, S. Chatterjee, J. Alloys Compd. 2017, 705, 817. 